DOI: $10.15421 / 272013$

UDC $625.21^{`} 656.27^{`} 656.3^{`} 625.144 .5^{`} 625.1^{`}$

\author{
M. Ruban*, B. Baka** \\ *Unit of Ukrainian Railways Historical Heritage of the Department of corporate social \\ responsibility of JSC «Ukrzaliznytsia», Volodymyr Dahl East Ukrainian National \\ University, Kyiv, Ukraine \\ **Department «Management of energy processes» of Dnipro National University of \\ Railway Transport named after academician V. Lazaryan, Dnipro, Ukraine.
}

\title{
FORMATION AND DEVELOPMENT \\ OF MAIN-LINE ELECTRIC LOCOMOTIVE ENGINEERING \\ IN INDEPENDED UKRAINE (1991 - 2008)
}

E-mail: nikolas.kindle@gmail.com

ORCID ID: https://orcid.org/0000-0002-6396-4531

E-mail: bakabogdan24@gmail.com

ORCID ID: https://orcid.org/0000-0001-7036-4326

\begin{abstract}
The Ukrainian transport engineering industry has a deep historical tradition that goes back to the activities of the Odesa railway workshops and the establishment of specialized locomotives in Kharkiv and Lugansk. The electric locomotives industry in Ukraine is represented by the products of the Dnipro plant, which for a long time produced electric locomotives of a purely industrial purpose. In the early 1990s, to upgrade the locomotive fleet of Ukrainian railways in the absence of foreign exchange funds for the purchase of traction rolling stock abroad, the management of Ukrzaliznytsia, together with the line ministries, decided to provide the organization of the main-line electric locomotives based on the Dnipro plant.

During the implementation of the state program of mainline electric locomotives construction, the Dnepropetrovsk plant developed, and subsequently implemented, projects of a freight DC electric locomotive DE1, an AC cargo and passenger electric locomotive DS3, and also based on DS3 began technical research on a two-system electric locomotive with an asynchronous drive DS4.

The Dnipro electric locomotive engineering plant, with its powerful scientific and production potential and clear development strategy, carried out the development and created the next generation's main electric locomotives to meet the needs of Ukrainian railways with modern electric transport. Unfortunately, due to the traditional lack of funding and lobbying on the part of Russian machine-building enterprises, the Dnieper electric locomotives have not become the main locomotives of Ukrainian railways. Unfortunately, due to the economic-financial crisis of 2008, all the prospective achievements of the said enterprise were virtually offset and the plant itself was in a difficult position. However, it is clear that the historical experience of becoming a Ukrainian scientific and production base of railway engineering needs to be properly considered.

The proposed study does not deplete the raised problem in the field of the Dnipro electric locomotive plant's activities, but only provides a general analysis and factual basis for further, more detailed review of the maintenance and development of national railway engineering in independent Ukraine, leaving considerable space for further scientific research.
\end{abstract}


Keywords: Dnipro electric locomotive plant, transport engineering, main-line locomotive engineering, Ukrainian railways.

\section{М. Ю. Рубан*, Б. О. Бака**}

*Відділ історичної спадщчини залізниць України Департаменту корпоративної сочіальної відповідальності АТ «Укрзалізниця», Східноукраӥнський національний університет імені Володимира Даля, Київ, Україна

**Факультет управління енергетичними процесами Дніпровського національного університету залізничного транспорту ім. академіка Лазаряна, Дніпро, Україна

\section{СТАНОВЛЕННЯ ТА РОЗВИТОК МАГІСТРАЛЬНОГО ЕЛЕКТРОВОЗОБУДУВАННЯ В НЕЗАЛЕЖНІЙ УКРАЇНІ (1991-2008)}

Анотація. Здійснено спробу дослідження історичних обставин становлення та розвитку магістрального електровозобудування в незалежній Україні (1991-2008). Українське транспортне машинобудування має глибокі історичні традиції, що сягають діяльності Одеських залізничних майстерень та заснування спеціалізованих локомотивобудівних заводів у Харкові та Луганську. Електровозобудівна галузь в Україні представлена продукцією Дніпровського заводу, який протягом тривалого часу виробляв електровози виключно промислового призначення. На початку 1990-х рp. 3 метою оновлення локомотивного парку українських залізниць на тлі відсутності валютних коштів для закупівлі тягового рухомого складу за кордоном, керівництвом «Укрзалізниці» спільно 3 профільними міністерствами було вирішено забезпечити організацію виробництва магістральних електровозів на базі Дніпровського заводу. На жаль, внаслідок економічної фінансової кризи 2008 р. усі перспективні досягнення вказаного підприємства були фактично нівельовані, а сам завод опинився у скрутному становищі. Однак, безумовно, що історичний досвід становлення української науково-виробничої бази залізничного машинобудування потребує свого належного осмислення. Отже, у статті проаналізовано історію Наукововиробничого об’єднання «Дніпровський електровозобудівний завод» (згодом Науково-виробничий комплекс «Електровозобудування») 1991-2008 рр.

Ключові слова: Дніпровський електровозобудівний завод, транспортне машинобудування, магістральне електровозобудування, українські залізниці.

\section{Introduction}

The field of transport engineering in Ukraine has a deep historical tradition. The first Ukrainian steam locomotives of the tandem compound system were built with the personal participation of O.P. Borodin based on the Main Railway Workshops of the Southwest Railways Society during $1894-1897$ [12, p. 140, 202]. At the end of the nineteenth century leading specialized centers of steam generation in Kharkiv and Lugansk were formed. On December 17, 1897, the first locomotive of the Kharkiv plant was built [1, p. 28], and only on May 29, 1900 - the Lugansk plant [9, p. 21]. In the postwar period $(1947-1961)$ the staff of the Kharkiv Transport Machine-Building Plant (former steam engine) began the newest era of heat generation in the Soviet Union, developing a sound technical base to create the majority of future series of locomotives for Lugansk and Kolomna. 
In the territory of the former USSR main electric locomotives were built only at Novocherkassk (Russia) and Tbilisi (Georgia) plants [14, p. 20]. In Ukraine, the electric locomotives industry was represented by the products of the Dnipro plant, which since 1958 produced electric locomotives for industrial purposes. In the early 1990s, there was a need to upgrade the locomotive fleet of Ukrainian railways. In the absence of foreign exchange funds for the purchase of a sufficient number of traction rolling stock abroad, the management of «Ukrzaliznytsia» jointly with the line ministries decided to combine the purchase of foreign locomotives with the organization of production of TRS at the factories of domestic industry [14, p. 94]. Therefore, the implementation of the program for the organization of production of main electric locomotives of all kinds was assigned to the Dnipro plant.

Unfortunately, for a long time, the circumstances of the production activity of the Dnipro Electric Locomotives Plant have not found their proper coverage in national historiography. Some issues of the history of the enterprise are presented in engineering and technical intelligence $[8 ; 10 ; 11 ; 13 ; 15]$, in most historical and technical publications, however, there is no mention of the Dnipro Electric Locomotives Plant [4, p. $30-41$ ]. However, these works do not exhaust the fullness of the topic and require the introduction of additional new scientific sources. The analysis of the history of the development of the enterprises of the transport mechanical engineering of Ukraine becomes of acute urgency against the background of the general reformation of the national railway industry, the need to update the traction rolling stock and the need to take into account the historical experience of resolving the said issue.

Therefore, the subject of the proposed research is the production activity of the Dnipro Electric Locomotives Plant, which provides the following research tasks: firstly, to find out the historical circumstances of the Dnipro Electric Locomotives Plant; secondly, to consider the prerequisites for batch construction and technical features of Ukrainian electric locomotives; thirdly, to find out the reasons for the decline of the Ukrainian backbone electrical generation. The chronological boundaries of the study cover the period from the time of formation of the main electric locomotives generation at the Dnipro Electric Locomotives Plant to the time of the actual curtailment of production of the main electric locomotives at the enterprise in 2008.

The purpose of the article is to create a holistic picture of historical prerequisites of the formation and circumstances of the development of main electric locomotives generation in independent Ukraine based on a comprehensive analysis of historical sources, periodicals and scientific literature.

\section{History of RPA «Dnipropetrovsk Electric Locomotives Plant»}

The Dnieper electric locomotives plant was founded in 1934 as an enterprise for the repair of industrial steam locomotives within the USSR Heavy Industry Commissariat. In 1958 the plant was reorganized into the Dnepropetrovsk electric locomotives plant (DELP). The Dnepropetrovsk plant specialized on the production of electric locomotives for the mining and quarrying industry, quarries, mining and processing plants and mines. The enterprise had a rather powerful special design and technological bureau, which was institutionally separated in 1970. The team of the Dnipro SCTB developed several unique projects of 12-axis specialized traction units and narrow-gauge electric locomotives, which were successfully implemented at production capacities. 
After the declaration of independence of Ukraine in 1991, the DELP was led by Valery Chumak, whose name is related to the history of the formation of the main electric power generation at the enterprise. On June 26, 1993, the Cabinet of Ministers of Ukraine approved Resolution No. 480 «On the Design and Production of Main Freight and Passenger Electric Locomotives» [3]. Since backbone electric locomotives were not produced in Ukraine at the time, the tasks of the DELP and SCTB teams were to be solved. In 1995, during the implementation of the state order, the SCTB was reorganized into the Ukrainian Research Institute of Electrical Engineering (hereinafter - URI Electric Engineering), headed by Academician Victor Bratash. In the same year, the Dnepropetrovsk electric locomotives plant was established based on the DELP and URI of electrical engineering [3].

With regard to the economic crisis of the early 1990s, the issue of electrification of the entire railway network of Ukraine was considered to minimize the cost of energy resources [14, p. 20], the organization of the production of electric locomotives was given special importance. In 1996, the financing of the electric power line was identified as a priority in the overall sequence of «Ukrzaliznytsia» calculations [14, p. 66].

In August 1997, the Dnipro Plant was included in the list of enterprises of strategic importance for the economy and security of Ukraine. In 2003, the DELP and URI electric engineering teams, closely linked by a single production cycle, were merged into the State Enterprise «Electric locomotives engineering» Dnepropetrovsk Research and Production Complex» [13]. The quality management system according to the International Standard ISO 9001-2000 was implemented at the Electric Power Generation Company. In 2004, the company won the All-Ukrainian Competition for Product Quality of the «100 Best Products of Ukraine» in the nomination «Production of Productive and Technical Purpose». The big prize of the competition was awarded to the main electric locomotive DS3, and the electric locomotive DE1 received the finalist diploma [13].

\section{Freight DC electric locomotive DE1}

In fulfillment of the state order, the SPA "DELP" started the development of the first Ukrainian main electric locomotive - DE1, which was supposed to replace obsolete freight locomotives of the VL8 series in the locomotive park of the Dnipro and Donetsk railways. The main designer of the project was Academician V. Bratash. More than ten scientific centers and more than twenty Ukrainian enterprises have been involved in the creation of the new electric locomotive. The electrical units were supplied by Kharkiv RPA «Electrotyazhmash», Kyiv SPA «Quant» - electronic speed meters, and the «Chernihiv Instrumentation Plant had to produce diagnostic systems. 92\% of DE1 electric locomotive equipment was manufactured at domestic enterprises [14, p. 172].

The first electric locomotive DE1-001 was built in 1995. The authors borrowed basic design solutions from Soviet two-section freight locomotives, as well as Czech passenger electric locomotives. The locomotive consisted of two identical, interconnected sections, had a solid metal body with a supporting frame, as well as biaxial carts with axle units. On the roof in the front of the section were placed start-up resistors, in the rear of the current collector type asymmetric semi-pantograph and the main tanks [8, p. 13-14].

The locomotive contained some innovations and promising technical solutions. In particular, a new trolley, a new suspension, a principally new wiring diagram and a modernized pneumatic system were applied. The weight of the locomotive was 155 tons, the power $-6260 \mathrm{~kW}$, and the design speed $-100 \mathrm{~km} / \mathrm{h}$. The capacity of the DE1 locomotive was 5,100 tons (1.5 times higher than that of the VL-8 series locomotives). At 
a speed of up to $100 \mathrm{~km} / \mathrm{h}$, the locomotive consumed a quarter less energy, was equipped with a modern microprocessor control and diagnostics system «Trunk». The electric locomotive provides two types of electric braking-rheostat and recuperative. In both cases, the excitation windings of the traction motors are powered by a static converter, and the anchors remove the current produced by the motors. However, with rheostatic braking, the current is fed to the start-up braking resistors and converted to heat, and when recuperative returns to the contact network. For control of the power circuit and diagnostics of the equipment on the electric locomotive there is a control device of traction electric drive, consisting of four devices [8, p. 13-14].

In 1996, pilot electric locomotives DE1-001 and DE1-002 were tested. DE1-001 was tested at full load on the section Novomoskovsk - Dnipro, and later - NizhniDniprovsk-Knot - Chapline (total mileage $5000 \mathrm{~km}$ ). DE1-002 was tested on the territory of the plant and later transferred to the Dnieper railway. Electric locomotives were speeding up to $130 \mathrm{~km} / \mathrm{h}$ and were trains with a mass of 4,500 tons on the Dnipro Chapline section [3]. As the various locomotives were worked out on various locomotives, which were replaced at subsequent serial electric locomotives, in just a few years of operation they were written off due to significant wear and tear [8, p. 1-13].

In the fall of 1996, Volodymyr Savysko, Deputy Director of URI Electric Engineering, announced the completion of the development of the passenger electric locomotive DE2, the DE3 and DE4 series were to be in the queue, however, further development and implementation of these models were discontinued due to lack of funding [3].

In the second half of 1998 RPA «DELP», taking into account all the shortcomings and problems of operation of the first two lcomotives, released the electric locomotive DE1-003. Subsequently manufactured electric locomotives DE1 by the numbers 004, 005, 006, 007 were similar in design to DE1-003 and arrived at the locomotive depot of Nizhni-Dniprovsk-Knot [8, p. 12]. During 2001, the first electric locomotives of the DE1 series began to arrive at the locomotive park of the Donetsk railway. In March 2001 the electric locomotive DE1-009 was tested at the Yasinovata depot [6], and in December 2001 the electric locomotive DE1-012 went to the Liman depot. Subsequently, all DE1 locomotives on the Donetsk Railway were transferred to the Liman depot, where a special column of locomotive crews was formed soon to work on these locomotives [7].

In December 2002, the work «The Development, creation, development and production of a domestic eight-axis electric locomotive of direct current type DE1» was awarded the State Prize of Ukraine in the field of science and technology [13]. RPC "Electric Locomotives Engineering" was ready to produce 25-30 electric locomotives per year, however, after the release of 20 electric locomotives in 2003, the issue of the beginning of industrial production of electric locomotives DE1 has not been resolved at the government level. At that time the cost of one DE1 locomotive was 30-35\% lower than the cost of foreign analogues [8, p. 14]. In total, 40 electric locomotives of DE1 were manufactured, which are now evenly distributed between the depot of the Nizhni Dniprovsk-Knot of the Dnieper railway and the Lyman of the Donetsk railway.

\section{Freight and passenger AC electric locomotive DS3}

The next stage in the development of the domestic electric power line is the creation of a universal passenger electric locomotive of alternating current - DS3, which was supposed to replace obsolete Czech passenger locomotives of the Emergency Series. 
This work was carried out jointly with the German concern Siemens and RA «Electrotyazhmash» (Kharkov). The Siemens Group actively participated in the design of the body and supplied the control system equipment, RPC «Electric locomotives engineering» manufactured mechanical parts and auxiliary machines, and «Electrotyazhmash» - traction motors [13].

The prototype DS3-001 was manufactured in the fall of 2002. The electric locomotive had a traction capacity of $4.8 \mathrm{MW}$, developed a maximum speed of up to 160 $\mathrm{km} / \mathrm{h}$ and was 1.5 times cheaper than its foreign counterparts. The mechanical part of the locomotive was largely unified with the locomotive DE1. The transmission of traction and braking power to the frame of the locomotive was provided by inclined drafts, one per cart. The locomotive was equipped with three-phase asynchronous traction motors with a short-circuited rotor. The traction motors were powered from two transformers with a linear voltage up to $2200 \mathrm{~V}$. The vector control of the transformers, as well as other electric locomotive equipment, was carried out by the microprocessor system. The mode of operation of the traction motors was set by a reversing switch and two handles. The auxiliary machines also had an asynchronous drive. Two centrifugal motor fans were installed to cool the traction motors on the electric locomotive, and two V-shaped fourcylinder compressors were supplied to supply compressed air. Both the passenger and cargo air distributors were installed on the pneumatic panel, which determines the possibility of using the DS3 in both types of traffic [2].

At the end of 2003, the DS3 electric locomotive successfully passed the acceptance tests conducted by the interagency commission, composed of representatives of «Ukrzaliznytsia», line ministries, related companies and Siemens. The use of DS3 electric locomotives should have increased the capacity and cost-effectiveness of rail transport in Ukraine. In 2004, the production of a pilot batch of 18 locomotives was started [5]. «Ukrzaliznytsia» has concluded a preliminary agreement with the RPC «Electric locomotives engineering» on the production and delivery of 100 units of electric locomotives of DS3 [5]. It is noteworthy that the Russian «Transmashholding», seriously fearing competition from the Ukrainian-German development, blocked the demonstration of the locomotive at the Russian exhibitions. In total, 18 DS3 electric locomotives were manufactured and delivered to the locomotive depot of the Kyiv-Passenger Southwestern Railway [15].

\section{Two-system electric locomotive DS4}

In the early 2000s, there was a need in Ukraine to organize the production of a universal dual-system electric locomotive capable of operating on both direct and alternating current. At "Ukrzaliznytsia" locomotive park, similar equipment was introduced by outdated VL82 electric locomotives of the 1970s construction, which at that time did not meet the speed and power requirements. Structurally, VL82 locomotives were freight locomotives, however, in the absence of other options, they were often used to provide passenger transportation. Since in Ukraine the VL82 locomotives and the modernized VL82M series had no more than 50 units, there was a need not so much for the railways as a significant expansion of the two-locomotive locomotive fleet [5].

Successful experience of DS-3 electric locomotives has pushed the staff of RPC «Electric Locomotives Engineering» to the idea of developing on its basis a two-system electric locomotive DS4. This universal electric locomotive, with a speed of up to 200 $\mathrm{km} / \mathrm{h}$, had to significantly speed up passenger transportation and eliminate downtime at the docking stations of electrical systems. However, the release of electric locomotives 
DS4 has not been adjusted. Unfortunately, the management of the Dnipro plant, referring to the trade secret, did not comment on the fate of this project [5].

\section{The decay of the Ukrainian backbone electric locomotives engineering}

The global economic crisis of 2008 significantly complicated the situation of the Dnipro Electric Locomotives Plant. Supplies of DS3 electric locomotives sharply decreased: out of 101 planned units, only 18 were purchased, to which only 3 were to be added in 2009 [5]. In 2008, the Russian electric locomotive 2ES4K received a certificate of conformity and was put into production. As the cost of one locomotive 2ES4K, taking into account transportation and customs clearance, was lower than the cost of production of DE1, the Ukrainian electric locomotive did not withstand competition and its further issue was stopped [8, p. 14].

Updating of the project of a two-system electric locomotive with an asynchronous drive was provided by the updated Comprehensive program of updating of the railway rolling stock of Ukraine for $2008-2020$. However, according to the director of «Ukrzaliznytsia» Mykhailo Kostyuk: «We are not satisfied with the belated policy of a domestic manufacturer that invests in the development of outdated technology» [5]. This meant that both the DS-3 electric locomotive and the DS-4 based on it became uninteresting for the new management of Ukrainian railways.

In 2010, «Ukrzaliznytsia» together with the Siemens concern announced the beginning of works on the creation of the main two-line electric locomotive, but already at the capacities of the Zaporizhzhya Electric Locomotives Repair Plant. The agreement envisaged the development and production of the first 10 locomotives at Siemens factories with pilot tests in Ukraine, and subsequently the gradual transfer of production to the OJSC «Zaporizhzhia Electric Locomotives Repair Plant» [5]. However, this project also remained unfulfilled.

On May 10, 2018, the Cabinet of Ministers of Ukraine approved the decision on privatization of the Dnipro Electric Locomotives Plant until the end of 2018. The rest of the locomotives were suspended from work due to significant wear and tear on the background of horrific operation. In this regard, the question of organizing the overhaul and modernization of electric locomotives DE1 and DS3 arises, which, however, has already been successfully resolved by specialists of the L'viv Locomotive Repair Plant [11]. We hope that the unique models of the Ukrainian railway engineering will not only be preserved, but will also successfully operate on the network of domestic railways.

\section{Conclusions}

Thus, for a long time the Dnipro Electric Locomotives Plant, having a strong scientific and production potential and a clear development strategy, carried out the development and creation of new generation mainline electric locomotives to meet the needs of Ukrainian railways with modern electric transport. Unfortunately, due to the traditional lack of financing and lobbying on the part of Russian machine-building enterprises, Dnipro electric locomotives have not become the main locomotives of Ukrainian railways. However, taking into account the historical experience of the formation of the main electric power generation in Ukraine is of fundamental importance both in the general perspective of the development of the Ukrainian transport engineering and of the national railway industry in particular. 


\section{References}

1. Bystrichenko A. V., Dobrovolskyy Y. I., Drobotenko A. P. et al. (1995). KhPZ Malyshev factory. 1895-1995. A brief history of development. Kharkov: Prapor, 792 p. (in Russian).

2. DS3. Operating Instructions for the Siemens Supply Part (2006). Dnipropetrovsk, 49 p. (in Russian).

3. Gereilo $V$. Will there be a Ukrainian electric locomotive engineering? (1996). Magistral. December 3, no. 75 (225). Kyiv, p. 1, 3. (in Russian).

4. Haruk A. I. (2019). Made in Ukraine. Kharkov: Folio, 266 p. (in Russian).

5. Hrebeniuk Y. «Ukrzaliznytsia» is looking for an electric locomotive(2009). Economic news. November 16, no. 206 (1204). Kyiv, p. 4. (in Russian).

6. Krivko T. Oh very good native electric locomotive (2001). Zheleznodorozhnik Donbassa, August 23, no. 33 (10859). Donetsk, p. 2. (in Russian).

7. Krivko T. The column of testers (2002). Zheleznodorozhnik Donbassa, September 20, no. 37 (10913). Donetsk, p. 2. (in Russian).

8. Likhushyn Y. V. Electric locomotive DE1: creation and operation (2018). Locomotive inform, no. 11 (155). Kharkiv, Podvizhnoy sostav, pp. 12-16 (in Ukrainian).

9. Lugansk locomotives: people, years, facts (1996). Lugansk, 403 p. (in Russian).

10. Moiseiev S. A., Kolgashev S. L. Advantages and Disadvantages of DC Electric Locomotives Series DE1 и 2EL4 (2016). Locomotive inform, no. 7-8 (121-122). Kharkiv, Podvizhnoy sostav, pp. 35-44 (in Russian).

11. Prospects for modernization of domestic electric locomotives of series DE1 and DS3 in the conditions of Lviv locomotive repair plant (2018). Locomotive inform, no. 3-4. (117-118). Kharkiv, Podvizhnoy sostav, pp. 14-17 (in Ukrainian).

12. Rakov V. A. (1995). Locomotives of domestic railways (1845-1955.). Moscow, Transport, 564 p. (in Russian).

13. Shvaiko Y. Place in the transport market (2003). Magistral, April 18, no. 30 (809). Kyiv, pp. 6-7 (in Russian).

14. Ukrzaliznytsia. The progress of time. 1991-1996 (1996). Materials on the history of railway transport in Ukraine. Kyiv, Transport of Ukraine, 336 p. (in Ukrainian).

15. Zolotarov S. V. Locomotive depot Kyiv-Pasazhyrskyy - the main depot of the capital of Ukraine. (2018). Locomotive inform, no. 9 (153). Kharkiv, Podvizhnoy sostav, pp. 813 (in Ukrainian).

Received 16.02.2020

Accepted 20.02.2020 